\title{
SOCIALIZATION OF THE ESTABLISHMENT OF SAVE AND LOAN COOPERATIVES IN SRENGSENG KELURAHAN WEST JAKARTA
}

\author{
Rona Tumiur Mauli Carolin SIMORANGKIR \\ Mercu Buana University \\ rona_caroline@mercubuana.ac.id
}

\begin{abstract}
In this community service activity, we collaborated with the Srengseng village in community service activities, where the Srengseng village area was still under the Kembangan sub-district, West Jakarta. Currently, Srengseng Village is led by Mrs. Hj Rusmini. After we discussed this activity plan with the Lurah, Ibu Hj. Rusmini, the kelurahan has plans in the future to form a Savings and Loans cooperative in the Srengseng village environment considering that in the area there are many people who have micro, small and medium enterprises (MSMEs) where it is hoped that the planned formation of this cooperative will be an opportunity for the surrounding MSMEs in finding alternatives. funding their business. The targets of this community service are members of youth organizations, administrators of Family Welfare Empowerment (PKK) from Srengseng Village. Considering that when this activity took place the Covid 19 pandemic was still engulfing Indonesia and even the world, therefore this community service activity regarding the training for the formation of savings and loan cooperatives was carried out in one day, which was held through a webinar in a virtual meeting room (zoom application) held by a team of lecturers. Mercu Buana University by involving Srengseng Village and South Meruya Village, Kembangan District, West Jakarta. Training activities will be carried out on February 3, 2021 starting from 09.00 to 13.00 . The PPM activity on that day was attended by around 120 participants from the South Meruya and Srengseng villages. Community service activities were carried out by providing counseling for youth youth cadres, PKK women regarding the establishment of Savings and Loan Cooperatives. After attending the training, participants have more knowledge and understanding related to the formation of savings and loan cooperatives. From the webinar activity, there was also a question and answer session and discussion with participants with the implementing team, where it was concluded from the results of the discussion of the activity that a container was needed to accommodate the products of Micro, Small and Medium Enterprises, especially those around Mercu Buana University, especially during a pandemic like this. where their sales have decreased drastically, therefore they hope to work with the cooperative from Mercu Buana University to help sell these Micro, Small and Medium Enterprises products. At the end of the counseling event, we have provided a questionnaire to be given to the participants.
\end{abstract}

Keyword: Webinar, Kelurahan Srengseng, Cooperative, SME

\section{BACKGROUND}

Cooperatives are believed by many to be very compatible with the culture and way of life of the Indonesian people because they contain the principle of self-help, cooperation for the common good (mutual cooperation), and several other moral essences. With the largest number in the world, namely 209,000 units, cooperatives in Indonesia actually slumped. If managed properly, cooperative contributions can reach $68 \%$ of total gross domestic product (GDP) as in Denmark. This is because many cooperatives in Indonesia are not active, they are often used as a trick to rob government subsidies. This phenomenon explains that the growth in the quantity of cooperatives is not matched by the growth of good quality so that many cooperatives are passive. One of the obstacles is the lack of member participation in cooperative life.

Cooperatives are a form of economy that grows and is rooted in the culture of the Indonesian nation and in accordance with Pancasila as the basis of the state of the Republic of Indonesia, which is sovereign by the people and is a mandate from Article 33 of the 1945 Constitution. The existence of cooperatives as a teacher of economics is a separate phenomenon because there is no a legal entity or other similar business entity that is able to match it. Therefore, its existence is expected to be a counterweight to other economic pillars (StateOwned Enterprises and Private-Owned Enterprises).
Cooperatives are believed by many to be very compatible with the culture and way of life of the Indonesian people because they contain the principle of self-help, cooperation for the common good (gotong royong), and several other moral essences. With the largest number in the world, namely 209,000 units, cooperatives in Indonesia actually slumped. If managed properly, cooperative contributions can reach $68 \%$ of total gross domestic product (GDP) as in Denmark. This is because many cooperatives in Indonesia are not active, they are often used as a trick to rob government subsidies. This phenomenon explains that the growth in the quantity of cooperatives is not matched by the growth of good quality so that many cooperatives are passive. One of the obstacles is the lack of member participation in life

Cooperatives are one of the characteristics of the Indonesian people based on the principle of kinship. Cooperatives are still considered as the right place to solve people's economic problems. There are several types of cooperatives, namely based on the type of business and membership. From the type of business, there are consumption, production and savings and loan cooperatives. Cooperative members are people who are elected or bodies who want to become members, therefore cooperatives are a system that is already compatible with the Indonesian nation itself, therefore, in this way the people's economy will be better by 
holding an appropriate forum by the Indonesian nation. and therefore, a member of a cooperative is a person or entity who wants to join as a member voluntarily without coercion. Cooperatives have organizational instruments consisting of member meetings, management and supervisors. The role of cooperatives in supporting the national economy must be maximized, especially with the proliferation of foreign banks entering the micro sector because only $20 \%$ of existing cooperatives can be categorized as successful. The role of cooperatives can be divided into 2 , namely the benefits of cooperatives in the economic field and the benefits of cooperatives in the social field. Cooperatives are a form of joint business based on the principle of kinship. Cooperatives in Indonesia were first introduced by R. Aria Wiriatmadja in Purwokerto, Central Java in 1896. After Indonesia's independence on July 12, 1947, cooperatives held the first Cooperative Congress in Indonesia in Tasikmalaya. The pioneer was Mr. M. Hatta so that he was given the title of Father of Indonesian Cooperatives. The role of cooperatives in the national economy is as follows:

a. Help increase the income and prosperity of members in particular and society in general

b. Help improve business capabilities, both individuals and communities. c. Assist the government in providing job opportunities

d. Helping efforts to improve the standard of living of the community.

e. Organizing economic life in a democratic manner

f. Helping the development and development of the economic potential of members in particular and society in general

g. Strengthening the people's economy as the basis for the strength and resilience of the national economy.

In this community service activity, we collaborated with the Srengseng sub-district in community service activities, where the Srengseng village area was still under the Kembangan sub-district, West Jakarta. Currently, Srengseng Village is led by Mrs. Hj Rusmini. After we discussed this activity plan with the Lurah, Ibu $\mathrm{Hj}$. Rusmini, the kelurahan has a plan to form a Savings and Loans cooperative in the Srengseng sub-district, considering that there are many people in the area who have micro, small and medium enterprises (MSMEs) where it is hoped that the plan to form this cooperative will be an opportunity for nearby MSMEs in seeking alternative funding. their efforts

\section{METHOD}

\section{Place and Time}

Given that the Covid-19 pandemic has not ended yet, our group carried out this community service activity through a webinar activity through virtual facilities on February 3, 2021.

\section{Target Audience}

The targets of this community service are members of the youth organization, the management of Family Welfare Empowerment (PKK) from Srengseng Village, about 30-40 people. The reason why the members of the youth organization and PKK management were chosen is that they are expected to be more actively involved in the formation and involvement of the management and members of the savings and loan cooperative in the future and at the same time can motivate the community in the Srengseng Village to become members of the cooperative.

\section{Type of activity}

Community service activities are carried out by providing counseling for youth youth cadres, PKK women regarding the formation of Savings and Loans Cooperatives.

\section{Activity Techniques}

To support this community service activity, activity techniques are used to support the implementation of these activities. The following are the technical details of the activities to be carried out, namely:Metode observasi.

1. Monitor and record systematically the symptoms/ phenomena being investigated.

2. Determine the theme of service to be given.

3. Looking for Literature Studies.

4. Literature study is a technique of collecting reference data from various types of scientific sources that support the problem being solved. In this community service activity.

5. Creating Materials

6. Conduct outreach activities.

7. Given the current state of the Covid 19 pandemic, which makes it impossible to conduct face-to face counseling directly with participants, we plan to conduct counseling by doing it in a Webinar session followed by a question and answer session.

\section{Evaluation Mechanism}

At the end of the event, we have provided a questionnaire to be given to the participants. The purpose of giving the questionnaire is to evaluate the activities carried out and assess the participant's response to the activities held.

\section{RESULTS}

\section{Activity Implementation}

Considering that when this activity was taking place the Covid 19 pandemic was still engulfing Indonesia and even the world, therefore this community service activity regarding the training for the formation of savings and loan cooperatives was carried out in one (1) day, which was held through a webinar in a virtual meeting room (zoom application) held by a team of lecturers from Mercu Buana University involving Srengseng and South Meruya Villages, Kembangan District, West Jakarta. Training activities will be carried out on February 3, 2021 starting 
from 09.00 to 13.00 . The PPM activity was attended by around 120 participants from the South Meruya and Srengseng villages.

On this occasion the author and also acts as a resource person providing material that discusses the formation and governance of cooperatives that support the sustainability of MSME business in the future. It was also stated that cooperatives are an economic driving institution that is very suitable to be applied in Indonesia. Currently, Cooperatives are a place where members gather who share the same goal to improve a just and prosperous standard of living. Also presented in the webinar are the legal aspects of a cooperative institution, the requirements for an application for the legalization of a cooperative legal entity establishment deed, the process for legalizing a cooperative legal entity, the requirements for savings and loan cooperatives, cooperative management, and performance measurement of cooperatives. interested in pioneering cooperatives in various forms of creative economy. Examples include film cooperatives and creative communities such as Kabelan Coop in Sukomulyo Village, South Kaliwungu District, Kendal Regency.

From the webinar activity, there was also a question and answer session and discussion with participants with the implementing team, where it was concluded from the results of the discussion of the activity that a container was needed to accommodate the products of Micro, Small and Medium Enterprises, especially those around Mercu Buana University, especially during a pandemic like this. where their sales have decreased drastically, therefore they hope to work with the cooperative from Mercu Buana University to help sell these MSME products.

\section{Training Materials}

The material from the presentation is prepared and used as an interactive communication material (question and answer and discussion) between the resource persons and participants, and the material is made using a power point application.

\section{Activity Evaluation}

The implementation of this community service activity is also evaluated after the webinar is over. We prepared a questionnaire that was created in a google form which was distributed to participants to ask participants to evaluate the webinar events they had participated in. From the results of the evaluation, most of the participants gave a positive response to the results of the webinar implementation and requested that they be included in the upcoming community service event with different and interesting materials.

\section{CONCLUSIONS AND SUGGESTIONS CONCLUSIONS}

a. The community service activity which was held on February 3, 2021 which was carried out online went smoothly and received a positive response from participants consisting of youth organizations, PKK women and MSME actors. Participants seemed enthusiastic about participating in the event, as seen from the responses to questions posed by participants to the committee. Where the discussion that took place got a lot of responses and asked many questions. In the event there were also discussions that were beneficial for the participants and also received a positive response.

b. The participants stated that the training activity for the formation of a savings and loan cooperative was very useful, many 'new' things were obtained and learned during the activity. It can also be seen from the responses of participants who took part in the training material until the event was over.

c. The participants hope that this community service activity can continue in the future and can be a means of communication, friendship and with MSME actors, especially introducing the products sold and this activity as well as a manifestation of Mercu Buana University's social responsibility to the community around the campus.

\section{SUGGESTIONS}

It is hoped that community service activities such as those carried out in this activity do not stop there, but in the future it can continue to help the community around the Mercu Buana University environment, especially MSME actors to realize and develop their business

\section{REFERENCE}

https://mediaindonesia.com/read/detail/120164-koperasidan-umkm-harus- mampu hadapi-tantangan-global UU No. 25 Tahun 1992 Tentang Perkoperasian PP No. 4 Tahun 1994 Tentang Akta Kop PPNo. 17Tahun 1994Tentang Pembubaran Koperasi PP No. 9 Tahun 1995 Tentang Usaha Simpan Pinjam PP No. 33 Tahun 1998 Tentang Modal Penyertaan Koperasi Inpres No. 18 Tahun 1998 Tentang Pengembangan

Koperasi Kepmen No. 36 Tahun 1998 Tentang Penggabungan Koperasi Kepmen No. 35 Tahun 1998 Tentang Juklak USP Panduan Simpan Pinjam Koperasi 